\title{
POLÍTICA, MARKETING E NEOLIBERALISMO
}

\section{Pedro Roberto Ferreira}

O texto contém uma análise da relação política e sua possível consciência no seu momento específico compreendido pelo processo eleitoral (Londrina - eleições 92). Como este processo eleitoral em nos sos dias, nutre-se de algumas técnicas conhecidas como Marketing PolíticoEleitoral, e de como estas, contribuem para uma dinâmica de esvaziamento da vida política propriamente dita. Procura ainda, conectar esse esvaziamento político e suas consequências, com o avanço da concepção neoliberal cujo ápice parece fazer coincidir a política como mais uma manifestação de Mercado.

Palavras-chave: Processo político-eleitoral, Partido político; Consciência política; Marketing político-eleitoral, Neoliberalismo.

\section{A} pós o período da Ditadura Militar no Brasil, 1964-1985, o país viu-se imerso nas questões mais decisivas para a sua redemocratização. Da economia à política, passando pela cultura e educação, etc., pelo menos em alguns setores mais organizados da sociedade civil, discutiu-se um projeto objetivando a nova nação. $\mathrm{Na}$ raiz desta discussão, ganhava destaque a idéia de que a maioria da população não poderia arcar com os "custos" desse soerguimento da vida democrática.

Classe operária, trabalhadores em geral, já haviam sido penalizados por longo tempo,chegava 0 momento de mudanças de rumo e a classe dirigente deveria placidamente admitir a perda do seu "exclusivismo". Na época, não era raro aparecer nos discursos de figuras expressivas do meio empresarial, apelos para que a sociedade brasileira abandonasse preconceitos históricos e deixasse de ser excludente. A conquista da cidadania para todos, para a grande maioria da população até então "esquecida" pelo sistema, aparecia como o seu desaguadouro natural. Mas até hoje não se sabe se tais discursos foram frutos de um cinismo absoluto ou resultantes de um certo receio que pairasse sobre uma possível "revolta das massas". Ou ainda, porque não, reflexos de uma sensibilidade tardia, isolada no interior da classe social, embora presente e provocativa para os "corações" mais empedernidos.
Sem desprezar o approach histórico explicativo da formação da sociedade burguesa no Brasil, onde verifica-se que pôde ser descartada uma violenta luta interna revolucionária, já que a burguesia não teve que enfrentar uma aristocracia feudal; os atores burgueses dispensaram a apresentação de um programa geral - um programa político para todos. Em outras palavras, a burguesia não precisou de uma proposta de governo que fosse a da nação, a da maioria da população . A edificação do capitalismo brasileiro não gerou uma luta da burguesia contra grupos dominantes anteriores. A burguesia nacional não lançou mão do regime democráticoliberal, posto que o apoio dos operários, dos trabalhadores, enfim, da maioria da população brasileira não lhe era necessário. Deste modo, a sociedade burguesa formou-se excluindo da participação política - o povo, criando uma estrutura de poder centralizadora, autoritária, um Estado que agia de maneira brutal - frente as questões sociais, populares, etc.

Saltando um período histórico compreendido por vários décadas e adotando o governo de E. Geisel (1974-1979) como o ponto de partida para este texto, percebe-se que muita coisa mudou na sociedade burguesa do Brasil, todavia sempre mantendo suas características básicas, corporificadas no domínio de uma classe dirigente e pouco permeavel às novas exigências do tecido social.

\footnotetext{
- Prof. do Departamento de Ciências Sociais da Universidade Estadual de Londrina.
} 
Com o governo de Ernesto Geisel a Ditadura Militar elaborou e implementou o PND2 (Plano Nacional de Desenvolvimento-2), que privilegiou a indústria de bens de capital, mas já em um contexto internacional do capital financeiro bastante adverso. Um setor da burguesia nacional não foi contemplado nesse plano e começou a fazer uma oposição soft à Ditadura Militar. Esta oposição vai se somar à dos operários, de certos segmentos médios, que foram explorados economicamente com baixos salários e quase nenhuma assistência social. Aí, nasce um movimento social que será muito significativo nos anos oitenta.

A crise do capitalismo internacional nos anos setenta, reflete no Brasil fundamentalmente em dois aspectos: desaceleração dos investimentos de capital estrangeiro e a cobrança da "dívida" contraida nos chamados anos do "milagre econômico" (1969-1972). Sem dúvida, tais reflexos, colocavam alguns complicadores no processo de redemocratização que deveria realizar-se ainda na vigência de um sistema capitalista. Até porque, 0 advento da redemocratização deveria implicar, não se deve esquecer, cidadania para a maioria da população brasileira. Isto é, direitos sociais mais direitos políticos, inclusive, para uma população que sempre viveu à margem do sistema econômico de "livre iniciativa". Uma verdadeira "revolução burguesa"em um país já plenamente capitalista, mas no momento, sob as malhas de uma pressão da economia internacional que começava a intensificarse.

Um marco desse impasse nas relações entre economia nacional e internacional pode ser observado durante o governo de E.Geisel. No seu início, a denominada "crise do petróleo", foi enfrentada com um aporte de capital externo e com aumento do endividamento já outrora contraido; no final do seu mandato, o quadro econômico impunha reformulações internas voltadas sobretudo, para a geração de uma matéria -prima especial - a energia. As medidas internas que foram aplicadas não aplacaram o binômio crise econômica/custo social, sendo que em vários casos, os principais problemas foram até acentuados.

Cada vez mais, sobressaía o caráter paradoxal da realidade brasileira; sua estrutura econômica bem desenvolvida revelada no imbricamento dos seus vários departamentos, funcionando sob efeitos perversos tais como: inflação, desemprego, sub/emprego, baixos salários, precaríssimas condições de vida nos grndes centros urbanos, etc.

Expressando muito bem a situação material e social da sociedade no Brasil, a vida política, especialmente, plano institucional, viu-se entrecortada por práticas negadoras dequaisquer aspirações democráticas. Fechamento do Congresso, reformulações casuísticas da estrutura político-partidária sempre às portas de processos eleitorais, bruscas alterações nas leis eleitorais, etc, marcaram esse momento da Política no Brasil, como reais indicadores da fixação de uma classe dirigente avessa ao projeto efetivo de redemocratização.

Nos anos oitenta, a classe dirigente continuará nutrindo enormes desconfianças dos movimentos sociais germinados na sociedade civil. Foi assim, diante de qualquer tentativa que pudesse trazer emancipações dos trabalhadores; veja-se o caso da organização do PT e da CUT, etc.

Durante a realização da "Constituinte-1988", a classe dirigente apresentou-se melhor organizada internamente, até mediante certas frações específicas que foram importantes na obstrução de algumas reformas econômicas e sociais contempladoras da cidadania com direitos sociais. O "centrão", a "UDR"e seus deputados, articularam no âmbito do Congresso Constituinte, um trabalho que impediu a introdução da reforma agrária, a estabilidade no emprego, etc, e que a despeito de pequenos avanços na legislação social, conseguiu manter 0 aspecto "excludente" do sistema capitalista no Brasil.

Para sustentar o referido comportamento na Constituinte/88, a classe dirigente não elaborou nenhum "novo" discurso e excluindo a reintrodução do conceito de modernidade cuja utilização justificava a redução do Estado na economia, nenhuma teoria surgiu para dar conta dos desafios impostos pela conjuntura nacional. Talvez, segundo a sua ótica, não fosse mesmo necessária. Por que indagar sobre a crise da economia se esta lhe proporcionava (e proporciona) lucros financeiros altíssimos?

A classe dirigente no Brasil fez coro com a burguesia internacional; que nunca conseguiu explicar no desenrolar dos últimos anos, as oscilações profundas da economia mundial. Nenhuma previsão sobre a "crise" veio acompanhada por "novas"conceituações teóricas da economia. A teoria econômica compromissada com o projeto da classe dirigente viu-se fragilizada ao pretender dar conta das bruscas alterações dos indicadores econômicos.

O Neoliberalismo, que a bem da verdade não é tão "neo" assim- arrola todos os problemas econômicos na tese da excessiva interferência do Estado na atividade produtiva porém no caso brasileiro, o grande Capital nunca abriu mão de uma proteção cambial e fiscal da parte do Estado, e o déficit público passa a ser tratado como o grande vilão da época atual.

Nas observações da concepção neoliberal, a modernidade requer a extirpação dos gastos sociais mantidos pelo Estado, posto serem fonte dos descontroles orçamentários e alimentadores, em últi-

\footnotetext{
${ }^{8}$ Para S.Brunhoff a crítica liberal ao Estado do Bem Estar Social já estaria presente nos anos 30 (POULANTZAS, 1977, p. 116) ver em. Já P.Anderson a coloca no pós 2a.G.G.Mundial com os trabathos do grupo austriaco; F. Hayek, Von Mises e outros (SADER \& GENTILLI, 1995, p. 9).
} 
ma instância, do processo inflacionário. Entretanto, enviesando toda a economia nacional, não se pode esquecer, existe o problema da dívida externa. Todo esforço econômico tem sido carreado para o pagamento do serviço da dívida, uma situação que exaure os recursos públicos que poderiam ser dirigidos para os novos investimentos reclamados pelo setor produtivo.

O Brasil procura obter os seus recursos no âmbito financeiro internacional, por meio de instituições como o Banco Mundial e o FMI, uma espécie de "instituição juiz" que aprova ou desaprova tais empréstimos, determina em quais condições deverão ser realizados. Assim, fala-se na necessidade da implementação de algumas medidas retiradas do receituário neoliberal cujo fim, seria tornar corrente um fluxo de capital privado internacional que pudesse alimentar 0 desenvolvimento econômico. Ora, tais medidas reclamadas, com certeza derrubariam o superávit comercial ( como de fato derrubou ) obtido justamente com uma certa regulamentação do mercado imposta por tarifas cambiais e fiscais e por outro lado não garantiriam a entrada de novos investimentos financeiros em setores produtivos.

A rigor, a discussão sobre o Estado instaurada pela classe dirigente, tem mais a ver com uma possível realocação de recursos que estão sendo transferidos de alguns setores da economia, para mantê-los sob a mira do processo permanente no nosso capitalismo - de privatização daquilo que é público. O processo da privatização das estatais no Brasil da forma como vem sendo realizado somente confirma tal assertiva.

Destarte, no decorrer deste processo histórico da ditadura à abertura - novos problemas foram gerados no interior dessa rica e complexa realidade social, determinando direções diferentes e até então desconhecidas, nos vários níveis constituintes da formação social brasileira.

Na Política, por exemplo, além do Estado ser bombardeado pela concepção neoliberal "auxiliada" pela a chamada crise do "socialismo real", mas que também comporta ingerências na vida econômica mesmo sob o sol do neoliberalismo, é possível observar no âmbito do processo eleitoral alterações que ocorreram com relação a sua forma de realização. Simultaneamente a uma "despolitização" das práticas efetuadas pelos partidos políticos, nota-se um avanço do denominado "marketing político" que somente reitera esta característica.

Não é raro na grande imprensa escrita, aparecer uma situação onde o terçar armas políticas, deu-se pelo embate de certos representantes de importantes agências de publicidade e não pela presença de significativas expressões políticas da nação ${ }^{9}$.

\footnotetext{
9 "Publicitários trocam Farpas" in Folha de S.Paulo, cd l, p.13, de 28 de março de 1993, - ver também "Assessor de Bill Clinton
}

Essa nova ocupação de espaço político não chega sem mudanças de alguma importância no processo político efetivamente dado. A utilização do marketing político deslocou o debate que bem ou mal girava em torno das propostas dos partidos políticos, para as técnicas de compra/venda geralmente empregadas no envolvimento dos consumidores postos pelo mercado capitalista. $\mathrm{E}$ os atores sociais são remetidos a uma dimensão, cuja marca principal é o isolamento, a subjetividade dos integrantes do conjunto social, a idiossincrasia dos indivíduos e a configuração de uma representação política solapada nos seus fundamentos de sociabilidade.

De um lado o candidato, do outro o eleitor; compreendidos numa relação direta, porém cravejada de valores estranhos à política exercitada por atores coletivos. Daí a substituição das aglomerações do comício pela individuação imposta pelo marketing veiculado no aparelho televisivo.

Em uma recente publicação de manual do candidato (marketing político), pode-se encontrar alguns preceitos oferecidos à reflexão do político/candidato, tais como: "Fale sempre bem das pessoas ausentes. Ao tomarem conhecimento elas o admirarão ainda mais"; "Procure sempre saber onde cada pessoa deseja chegar, mas não dê a entender que sabe"; "O apoio conquistado na concordância é efêmero. Mas na contrariedade, é perene"; "O interesse, o medo e o ódio são apelos fortíssimos, capazes de determinar em quem o eleitor vai votar" (KUNTZ; COMERLATTO; KOSTESKI, 1992, p. 133). É de se perguntar: qual a contribuição para a redemocratização, para a construção de uma efetiva cidadania na sociedade brasileira, que um candidato (e seu partido) assim municiado poderá oferecer?

Indubitavelmente, uma certa "despolitização" da sociedade civil sempre a gosto da classe dirigente, tem no marketing político um reforço natural. Portanto, até mesmo políticos que integram partidos mais críticos da ordem social (esquerda, socialdemocrata), que estiveram sob o seu efeito no momento atual, falam a partir desse contato, em uma política personalizada, num puro reflexo dessas mudanças em curso.

A análise do impacto do marketing político e suas consequências na política partidária institucional, deve considerar primeiramente a situação histórica do pluripartidarismo. Nunca esquecendo que este pluripartidarismo acha-se no nascedouro e movimenta-se conjuntamente com 0 processo da redemocratização. Assim, seu sucesso ou fracasso, expressará muito bem as possibilidades de democracia na sociedade capitalista no Brasil.

Nesse sentido, a investigação não ignorará que sendo esse pluripartidarismo vigente no país, fruto

ensina a ganhar eleição"in Folha de S.Paulo, cd 1, p.12, de 11 de julho de 1993. 
de um processo inicial que ainda conta com as marcas do clientelismo, do personalismo e determinadas práticas "fisiológicas", mas também, com organizações partidárias que buscam um filtramento mais democrático dos anseios produzidos na sociedade civil, deverá coexistir por um bom tempo com as pressões criadas por momentos favoráveis à utilização do marketing político.

Hodiernamente parece muito natural que os "projetos políticos"dos partidos, suas ideologias, etc, sejam substituídos por uma atividade articulada pela relação que isola o candidato e o eleitor das dimensões sociais geradoras das suas possiveis identidades. Até porque, retorna-se a predominância do entendimento de que o mercado livre é a fonte de toda a democracia, e aí, os indivíduos são indivíduos e não atores coletivos. A noção da relação simples de troca onde todos são compradores e vendedores, confere concretude e legitima a manipulação efetuada pelo marketing político.

A "venda" do candidato exigirá estratégia e táticas cujo comprador deverá também aparecer - o eleitor, posto que nenhum produto no mercado poderá dispensar o seu consumo, a sua realização. As agências de publicidade "compram"sua matéria-prima (o candidato) no mercado político, e a transforma em produto mediante imagens, formulações gráficas, etc, para seduzir os consumidores. No marketing político a Política não deixa de ser mais uma mercadoria. Daí a utilização de uma estratégia de vendas com toda a linguagem necessária e já empregada na comercialização de outros produtos.

A questão que começa a ser colocada por pesquisadores, jornalistas, pelos políticos mais conscientes, é: qual a integridade da "cidadania"frente a um movimento que parece levar a Política a uma certa mercadejarização? $\mathrm{E}$, até para uma esquerda que sempre nutriu desconfiança à temática da ci- dadania, que parece se orientar apenas pelas regras do Mercado?

No mínimo, o fato do projeto neoliberal ter se transformado em hegemônico (ANDERSON, 1995: 23), fez com que a taxa de militância nos partidos políticos conhecesse o seu pior índice. Assim, falar na queda da taxa de militância política é um truismo. E, como a militância está para a organização política (principalmente para os partidos de esquerda), o truismo se reitera ao se comentar a perda de importância e influência dos partidos políticos.

Neste processo irônico e trágico, quanto mais o partido político se aproxima da vida parlamentar, maisrapidamente se encaminha para a perda da sua significação política, posto muito depender do marketing político que lhe forja uma participação político-eleitoral vitoriosa.

A utilização do marketing político, desta maneira, se encontra em relação direta com o processo de descaracterização da prática política na atualidade, na medida ser este mais do que a simples manipulação de certastécnicas da comunicação.

\section{Referências Bibliográficas}

ANDERSON, P. "Balanço do Neoliberalismo". In SADER, E., GENTILLI, P. O Pós Neoliberalismo, Rio de Janeiro: Paz e Terra, 1995.

KUNTZ, Ronald A.; COMERLLATO, Tadeu; KOSTESKI, Claudino Como ser um Candidato Vitorioso. São Paulo: Maltese, 1992.

POULANTZAS, N. (Org.) O Estado em Crise Rio de Janeiro: Graal, 1977.

SADER, E. , GENTILLI, P. O Pós Neoliberalismo, Rio de Janeiro: Paz e Terra, 1995. 